\title{
Influence of mycorrhizal inoculation on growth of micropropagated Populus $\times$ canescens lines in metal-contaminated soils
}

\author{
Krystyna Bojarczuk • Leszek Karliński • \\ Teresa Hazubska-Przybył • Barbara Kieliszewska-Rokicka
}

Received: 16 February 2014/ Accepted: 23 September 2014/Published online: 2 October 2014

(C) The Author(s) 2014. This article is published with open access at Springerlink.com

\begin{abstract}
Micropropagated grey poplar (Populus $\times$ canescens (Aiton) Sm.) plantlets selected during in vitro culture as tolerant to toxic $\mathrm{Cu}$ and $\mathrm{Pb}$ ions, as well as control plantlets, were inoculated ex vitro with selected strains of ectomycorrhizal fungi (Hebeloma crustuliniforme, Paxillus involutus) and an arbuscular mycorrhizal fungus (Rhizophagus irregularis BEG 87) or not inoculated, and were grown for 8 weeks in a growth chamber. Successfully acclimatized microplants were transferred to a greenhouse and grown for 16 weeks in unpolluted soil irrigated during the cultivation period with solutions containing high concentrations of $\mathrm{Cu}$ or $\mathrm{Pb}$ ions or in soil contaminated with $\mathrm{Cu}$ and $\mathrm{Pb}$ collected $1 \mathrm{~km}$ from a copper smelter. Ectomycorrhizal inoculation enhanced the survival rate of plantlets during ex vitro acclimatization. Poplar microplants inoculated with $H$. crustuliniforme and selected strains of $P$. involutus accumulated higher concentrations of $\mathrm{Cu}$ and $\mathrm{Pb}$ when grown in contaminated soils than the uninoculated plants and reduced concentration of the metals in the soils. In conclusion, grey poplar microplants tolerant to heavy metals and inoculated with appropriate ectomycorrhizal fungi can facilitate the adaptation of these plants to metal-polluted soils and may be used for afforestation and phytoremediation of polluted land.
\end{abstract}

Keywords Copper $\cdot$ Lead $\cdot$ Metal-tolerant plantlets $\cdot$ Ex vitro acclimatization · Post-acclimatization

Electronic supplementary material The online version of this article (doi:10.1007/s11056-014-9455-3) contains supplementary material, which is available to authorized users.

K. Bojarczuk · L. Karliński · T. Hazubska-Przybył

Institute of Dendrology, Polish Academy of Sciences, Parkowa 5, 62-035 Kórnik, Poland

B. Kieliszewska-Rokicka $(\bowtie)$

Institute of Environmental Biology, Kazimierz Wielki University, Ossolinskich al. 12,

85-093 Bydgoszcz, Poland

e-mail: b.kielrok@op.pl; bkiel@man.poznan.pl 


\section{Introduction}

High concentrations of essential and nonessential trace metals in soil are potentially toxic to plants (Balsberg-Påhlsson 1989; Migeon et al. 2009; Zacchini et al. 2009) and soil microorganisms (Pennanen et al. 1996; Borghi et al. 2007; Wang et al. 2007). Areas impacted by copper smelters may be highly contaminated by $\mathrm{Cu}$ and $\mathrm{Pb}$ (Krzaklewski et al. 2004; Bojarczuk and Kieliszewska-Rokicka 2010; Medynska-Juraszek and Kabała 2012). High concentrations of the metals can reduce shoot and root growth and increase leaf senescence due to over-production of reactive oxygen species in plants (Luna et al. 1994; Pourrut et al. 2011).

Populus species, hybrids, and clones are fast-growing and deeply rooting trees, considered as good plant material for phytoremediation of metal-contaminated soils and groundwater (Borghi et al. 2007; Stobrawa and Lorenc-Plucińska 2007; Zacchini et al. 2009; Karlinski et al. 2010). Lines highly tolerant to increased concentrations of metals can be selected successfully in vitro on media containing metal ions; these lines can be applied for the afforestation of metal-polluted lands (Bojarczuk 2004a, b; Nehnevajova et al. 2007; Vera-Estrella et al. 2009). However, the high mortality rate of microplants during the postvitro steps of the propagation process is an important obstacle to the large-scale use of this method. In vitro or ex vitro biotization of microplants with mycorrhizal fungi and/or symbiotic bacteria enables to surmount the problems of acclimatization microplants to ex vitro conditions. Mycorrhizas improve plant growth and survival by enhancing water and nutrient uptake and protecting the plant against environmental stresses, including heavy metals (Smith and Read 2008). Both, ectomycorrhizal (ECM) and arbuscular mycorrhizal (AM) associations may play an important role in establishment of vegetation in highly polluted soils (Turnau et al. 2006). The ability to accumulate and detoxify heavy metals show ECM fungi (Turnau et al. 1996; Rudawska and Leski 2005; Ott et al. 2002; Luo et al. 2014; Ma et al. 2014) and AM fungi (Joner et al. 2000; Hildebrandt et al. 2007; Bissonnette et al. 2010; Bothe et al. 2010; Cicatelli et al. 2014). Mycorrhizal fungi can also enhance the host plant tolerance by influence on its defence genes (Polle et al. 2013). To date, few studies have reported on the effects of mycorrhizal fungi on the acclimatization of microplants of forest trees to ex vitro conditions. A positive effect of in vitro ECM inoculation on poplar growth was previously reported for Populus tremula L. $\times$ Populus tremuloides Mich (Hampp et al. 1996; Loewe et al. 2000) and for P. $\times$ canescens (Gafur et al. 2004; Li et al. 2012; Ma et al. 2014). Inoculation of microplants ex vitro with mycorrhizal fungi has been shown to improve poplar survival rate, health status, and growth post-acclimatization (Langer et al. 2008).

Populus spp. can develop dual mycorrhizal associations with ECM and AM fungi, however variable degrees of ECM and AM colonization have been observed in roots of various species and hybrids (Vozzo and Hacskalyo 1974; Khasa et al. 2002; Rachwał et al. 2003; Gehring et al.2006; Karlinski et al. 2010), suggesting differential predisposition of poplar genotypes to develop symbiotic associations with ECM or AM fungi. Natural tendency of poplar genotypes to develop symbiotic associations with ECM and AM fungi can be modified by environmental conditions, such as soil depth, soil moisture and contamination of soil with heavy metals (Karlinski et al. 2010, and literature cited there).

Grey poplar $(P . \times$ canescens $)$ is a natural hybrid between white poplar $(P . a l b a)$ and European aspen $(P$. tremula), occurring throughout Europe. $P . \times$ canescens has been shown to accumulate high amounts of $\mathrm{Cd}$ and $\mathrm{Zn}$ when grown in metal-polluted soil (Durand et al. 2011; He et al. 2013). ECM symbionts can influence physiological and molecular processes of the poplar and modify mechanism of heavy metal detoxification 
(Luo et al. 2014). No data were reported yet on a contribution of AM fungi in colonization of $P . \times$ canescens roots, but in several studies of $P . \times$ canescens microplants or cuttings have been colonized effectively with ECM fungi (Gafur et al. 2004; Langenfeld-Heyser et al. 2007; Luo et al. 2009b; Li et al. 2012; Ma et al. 2014). Species and strains of mycorrhizal fungi vary in their ability to develop mycorrhizal symbiosis with tree microplants (Gafur et al. 2004; Luo et al. 2009a, b), in their tolerance to toxic metals (Blaudez et al. 2000; Ma et al. 2014; Luo et al. 2014), and in their capacity for metal accumulation and detoxification (Rudawska and Leski 2005; Baldrian 2009; Luo et al. 2011). Choosing compatible and efficient mycorrhizal symbionts (species/isolates) is required to ameliorate successfully the negative impacts of toxic contaminants on plants (Gafur et al. 2004; Timonen et al. 2008; Li et al. 2012; Polle et al. 2013; Ma et al. 2014).

The aim of this study is to investigate (1) the effect of mycorrhizal inoculation of selected metal-tolerant grey poplar microplants on their survival rate during ex vitro acclimatization, and (2) the effect of mycorrhiza on poplar growth in the presence of increased concentrations of $\mathrm{Cu}$ and $\mathrm{Pb}$ in the soil. Selected strains of ECM fungi [Hebeloma crustuliniforme (Bull.) Quel. and Paxillus involutus (Batch) Fr.] that are natural ECM symbionts of poplars and AM fungus (Rhizophagus irregularis, syn. Glomus intraradices) (Schenck and Smith) known as an effective symbiont of a wide variety of plants were used to inoculate the microplants. We expected that mycorrhizal associations would enhance the survival and growth of selected metal-tolerant lines of grey poplar and improve their ability to colonize and clean up heavily contaminated soils.

\section{Materials and methods}

In vitro culture of poplar plantlets

Apical and lateral buds, as explants, were harvested from $P . \times$ canescens (Aiton) Sm. (=P. tremula L. $\times$ P. alba L., clone 1), originating from the collection of poplars of the Institute of Dendrology in Kórnik, Poland $\left[52^{\circ} 15^{\prime} \mathrm{N}, 17^{\circ} 04^{\prime} \mathrm{E}\right]$. In vitro culture was performed on modified half-strength MS medium (Murashige and Skoog 1962) supplemented with plant hormones $\left(0.1 \mathrm{mg} \mathrm{dm}^{-3}\right.$ 6-benzylaminopurine and $0.05 \mathrm{mg} \mathrm{dm}^{-3}$ 1-naphthaleneacetic acid) and solidified with Bactoagar $\left(8 \mathrm{~g} \mathrm{dm}^{-3}\right)$. To this medium, we added $0.08 \mathrm{mM} \mathrm{Cu}$ and $0.8 \mathrm{mM} \mathrm{Pb}$ as nitrates. The medium was adjusted to $\mathrm{pH} 4.5$. Poplar cultures were kept in $300-\mathrm{ml}$ jars at $22-23{ }^{\circ} \mathrm{C}$ in a growth chamber illuminated with mercury fluorescent lamps $\left(7,500 \mathrm{~mW} \mathrm{~m}^{-2}\right)$ for $16 \mathrm{~h}$ per day. From 6 to 12 passages maintained on medium with the heavy metals (HM+) were necessary to obtain the plantlets adapted to increased concentrations $\mathrm{Cu}$ and $\mathrm{Pb}$. The control plants were cultivated on the same medium without heavy metals (HM-).

Preparation of mycorrhizal inoculum

Mycelia of ECM fungi (H. crustuliniforme (Bull.) Quel. and P. involutus (Batch) Fr.) were isolated from fungal sporocarps collected in the experimental forest in Kórnik $\left(52^{\circ} 15^{\prime} \mathrm{N}\right.$, $17^{\circ} 04^{\prime} \mathrm{E}$ ) and were cultivated in Petri dishes on agar medium (Pachlewski and Pachlewska 1974). The mycelia of $H$. crustuliniforme and $P$. involutus were incubated for 6 or 3 weeks, respectively, at $22{ }^{\circ} \mathrm{C}$ before the mycelia were used for plant inoculation. One $H$. crustuliniforme isolate and three $P$. involutus isolates have been selected in a preliminary culturing in Petri dishes with increased $\mathrm{Cu}$ and $\mathrm{Pb}$ concentration in the agar medium 
( $\mathrm{pH} 4.5$ ), containing $0.5 \mathrm{mM} \mathrm{Cu}$ (as $\mathrm{Cu}\left(\mathrm{NO}_{3}\right)_{2} \cdot 3 \mathrm{H}_{2} \mathrm{O}$ or $1.0 \mathrm{mM} \mathrm{Pb}$ (as $\mathrm{Pb}\left(\mathrm{NO}_{3}\right)_{2}$, compared to control, which did not contained the heavy metals. We selected for ex vitro inoculation the fungal isolates of the tolerance indices higher than 0.8 (ratio of the diameter of metal-treated mycelium to the diameter of control mycelium) and the ability to form ectomycorrhizas with poplar plantlets in vitro.

Inoculum from the AM fungus Rhizophagus irregularis (syn. Glomus intraradices Schenck and Smith (isolate BEG 87) (Merrild et al. 2013), was propagated on maize (Zea mays L.) for 4 months in pots filled with a sterilized mixture of soil and quartz sand $(1: 1$ $\mathrm{v} / \mathrm{v})$. The colonization of maize roots by AM fungi was evaluated after visualization of the fungi in root samples (see details below). The average degree of root colonization was $89 \%$ RLC (root length colonized). The inoculum consisted of dry soil from the pot cultures and contained mycorrhizal mycelium, spores, and the colonized maize root pieces. The mycorrhizal activity of the inoculum was controlled with white clover cultivated for 8 weeks in pot cultures with soil and quartz sand (1:1 v/v), inoculated with BEG 87 . The average degree of white clover root colonization was $90 \%$ RLC.

\section{Experiment 1: effect of mycorrhizal inoculation on ex vitro acclimatization}

In vitro rooted plantlets of uniform size, the adapted to heavy metals $(\mathrm{HM}+)$ and the control plantlets $(\mathrm{HM}-)$ were transplanted ex vitro into plastic containers $\left(5.4 \mathrm{dm}^{-3}\right.$ in volume) filled with sterilized unpolluted forest soil $\mathrm{pH} 6.5$, mixed with unsterilized peat $(3: 1, v / v)$, or with sterilized quartz sand $(1: 1, \mathrm{v} / \mathrm{v})$ (eight plantlets per container). The soil and sand were sterilized by autoclaving at $121{ }^{\circ} \mathrm{C}$ and $1 \mathrm{~kg} \mathrm{~cm}^{-2}$ for $1 \mathrm{~h}$ on 3 successive days. The plantlets transplanted to the soil mixed with peat were inoculated with the ECM fungi: H. crustuliniforme, and three strains of $P$. involutus (Pax A, Pax B, or Pax C). Three mycelial plugs $(\varnothing 5 \mathrm{~mm})$ were placed under each plant. The plantlets transplanted to the soil mixed with sand were inoculated with AM fungus (50 g of inoculum per $1 \mathrm{~kg}$ of soil). The acclimatization process was conducted in the growth chamber (see above). During the first 3 weeks of acclimatization the plantlets were protected against water loss by plastic covers and irrigated with sterile deionized water to maintain $60 \%$ of the water capacity. Then the plastic covers were removed and the microplants were irrigated once per week with $50 \mathrm{ml}$ of sterile nutrient solution after Bojarczuk and Kieliszewska-Rokicka (2010), modified $\left(\mathrm{N}-\mathrm{NH}_{4}, 50 \mathrm{mg} \mathrm{dm}{ }^{-3} ; \mathrm{N}-\mathrm{NO}_{3}, 160 \mathrm{mg} \mathrm{dm}^{-3} ; \mathrm{K}, 2 \mathrm{~g} \mathrm{dm}^{-3} ; \mathrm{P}, 2.4 \mathrm{~g} \mathrm{dm}^{-3} ; \mathrm{S}\right.$, $2.7 \mathrm{~g} \mathrm{dm}^{-3}$; Cu, $5 \mathrm{mg} \mathrm{dm}^{-3} ; \mathrm{Fe}, 100 \mathrm{mg} \mathrm{dm}{ }^{-3} ; \mathrm{Mn}, 27 \mathrm{mg} \mathrm{dm}^{-3} ; \mathrm{Mo}, 5 \mathrm{mg} \mathrm{dm}^{-3}$; and

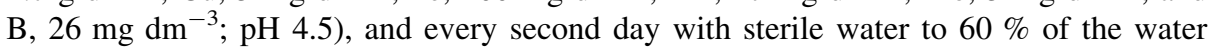
capacity. The experiment ended 8 weeks after transplantation. Survival rate of the poplar plants and the mycorrhizal status of their roots were assessed.

\section{Experiment 2: effect of mycorrhiza on $\mathrm{Cu}$ - and $\mathrm{Pb}$-treated microplants}

After 8 weeks of acclimatization in the growth chamber, the plantlets of the heavy-metal adapted poplar line (HM+) inoculated with the mycelia of $H$. crustuliniforme, $P$. involutus (strains A, B, and C), Rhizophagus irregularis (BEG 87) and the uninoculated microplants were planted in pots ( $17 \mathrm{~cm}$ in diameter, $13 \mathrm{~cm}$ high, $1.4 \mathrm{dm}^{3}$ in volume) filled with unpolluted, unsterilized soil collected from a collection of poplar clones in Kórnik, mixed with peat $(3: 1 \mathrm{v} / \mathrm{v})$. One plantlet was planted per pot, $15-18$ plans per variant. Plants were grown for 16 weeks in a greenhouse for the period between May and August, and were treated or not treated with increased levels of $\mathrm{Cu}$ or $\mathrm{Pb}$. Substrate moisture was adjusted to $60 \%$ water holding capacity every second day and the soil was irrigated once per week 
$\left(0.05 \mathrm{dm}^{3}\right.$ per pot) with the nutrient solution (as in the exp. 1) and once per week with $0.05 \mathrm{dm}^{3}$ per pot of $4 \mathrm{mMCu}\left(\mathrm{NO}_{3}\right)_{2} \cdot 3 \mathrm{H}_{2} \mathrm{O}$ or $4 \mathrm{mM} \mathrm{Pb}\left(\mathrm{NO}_{3}\right)_{2}$ water solutions $(\mathrm{pH} 4.5)$. The control and the treated plants were supplemented with adequate amounts of $\mathrm{HNO}_{3}$ solution to obtain equal concentration of nitrogen in the control and the metal-treated variants.

Experiment 3: effect of mycorrhiza on microplants grown in soil heavily contaminated with $\mathrm{Cu}$ and $\mathrm{Pb}$ (Głogów copper smelter)

P. $\times$ canescens microplants selected in vitro as metal-tolerant $(\mathrm{HM}+)$ and inoculated during acclimatization with mycorrhizal fungi (H. crustuliniforme, Paxillus involutus strains $\mathrm{A}, \mathrm{B}$, and $\mathrm{C}), R$. irregularis as well as uninoculated control plants were planted in pots (17 $\mathrm{cm}$ in diameter, $13 \mathrm{~cm}$ high, $1.4 \mathrm{dm}^{3}$ in volume) filled with a growth medium consisting of metal-polluted soil and peat, $(3: 1, \mathrm{v} / \mathrm{v})$. The polluted soil taken from the vicinity of the Głogów copper smelter $\left(51^{\circ} 37^{\prime} \mathrm{N}, 16^{\circ} 07^{\prime} \mathrm{E}\right)$, contained high concentrations of $\mathrm{Cu}$ and $\mathrm{Pb}$ (Table I-supplement). Control growth medium was unpolluted forest soil taken from Kórnik (see above), mixed with peat ( $3: 1 \mathrm{v} / \mathrm{v})$. One plantlet was planted per pot, 15-18 plants per variant. The plants were grown for 16 weeks between May and August in a greenhouse and were irrigated every second day with water by adjusting the soil moisture to $60 \%$ water capacity. Once per week each of the pots was irrigated with $0.05 \mathrm{dm}^{3}$ of nutrient solution (as in the exp. 1).

Plant harvest and analyses

A destructive harvest was conducted after the growth period. Individual plants were separated into leaves, stems, and roots. Soil was washed from the roots very carefully for 5 min with tap water to remove adherent particles, and the roots were further rinsed three times with demineralized distilled water. The number of root tips, and the root length were measured using the image analysis systems WinRhizo (version 5.0) (Reagent Instruments Inc., Quebec, Canada). Three selected leaves (numbers 5-7 when counting from the top) were taken for leaf dry mass. Samples of the roots were stored in $50 \%$ ethanol for later microscopic evaluation of mycorrhizal colonization. All parts of the plants assigned for biomass evaluation were weighed immediately, then oven-dried to constant weight at $65^{\circ} \mathrm{C}$ before the determination of dry weight.

Soil and plant chemical analyses

At the beginning of experiment 1 and at the end of experiments 2 and 3, the concentrations of the soluble forms of macro- and micronutrients and pollutants were measured in the soils. Soil samples were sieved (mesh size $4 \mathrm{~mm}$ ) and visible plant material was removed before air drying. Macronutrients were analyzed in an extract of $0.03 \mathrm{~N}$ acetic acid. Micronutrients and pollutants were extracted in a modified Lindsey solution, which contained in $1 \mathrm{dm}^{3}: 5 \mathrm{~g} \mathrm{EDTAH}_{4}, 9 \mathrm{ml} 25 \%$ ammonia, $4 \mathrm{~g}$ citric acid, and $2 \mathrm{~g}\left(\mathrm{CH}_{3} \mathrm{COO}\right)_{2} \mathrm{Ca}$ $2 \mathrm{H}_{2} \mathrm{O}$ (Komosa and Szewczuk 2002; Lindsay and Norvell 1978). After extraction, $\mathrm{N}-\mathrm{NH}_{4}$, $\mathrm{N}-\mathrm{NO}_{3}$, and $\mathrm{S}-\mathrm{SO}_{4}$ were assayed with ion-selective electrodes; $\mathrm{P}$ was assayed colorimetrically with ammonium molybdate; $\mathrm{K}, \mathrm{Ca}$, and $\mathrm{Na}$ were assayed with flame photometry; chlorides and sulfates were assayed with nephelometrically; and $\mathrm{Mg}, \mathrm{Fe}, \mathrm{Mn}, \mathrm{Zn}, \mathrm{Cu}$, $\mathrm{Pb}$, and $\mathrm{Cd}$ were assayed with atomic absorption spectroscopy. Soil $\mathrm{pH}$ was determined in 1:2.5 (w/v) soil-water suspension. 
Roots, stems and leaves were dried at $60{ }^{\circ} \mathrm{C}$ for $48 \mathrm{~h}$. The concentrations of selected elements were measured in the plant material as follows: total $\mathrm{N}$ by the micro-Kjeldahl method and the concentrations of $\mathrm{P}, \mathrm{K}, \mathrm{Ca}, \mathrm{S}, \mathrm{Mg}, \mathrm{Fe}, \mathrm{Mn}, \mathrm{Zn}, \mathrm{Cu}, \mathrm{Pb}$, and $\mathrm{Cd}$ by the same methods as described for soil analyses.

Analyses of mycorrhizal colonization

Fine roots were cut into sections $\sim 1 \mathrm{~cm}$ long and soaked in distilled water. ECM root tips were distinguished under a stereomicroscope (magnification $8-50 \times$ ). One hundred 1-cm root pieces per plant were examined to determine the number of root tips and the percentage of ECM colonization. ECM morphotypes were distinguished on the basis of morphological traits such as color, branching pattern shape, structural features of the hyphal sheath (mantle). The relative abundances of ECMs from each morphotype were calculated separately for each plant as the proportion of root tips of a given morphotype relative to the total number of root tips within the sample.

Five single ECM root tips from each of the main morphotypes were stored in a $2 \%$ cetyltrimethylammonium bromide buffer for DNA analysis. ECM fungi were identified by sequencing the PCR-amplified internal transcribed spacer of the rDNA according to the method developed by Gardes and Bruns (1996) and described by Leski et al. (2010). The resulting sequences were compared with published sequences in the UNITE or NBCI databases using BLAST.

To visualize AM colonization, the segments of the poplar fine root were stained according to Kormanik and McGraw (1982), with modifications. The poplar roots were cleared in $10 \%$ $\mathrm{KOH}$ for $1-2 \mathrm{~h}$ at $90{ }^{\circ} \mathrm{C}$, bleached for $1 \mathrm{~h}$ in alkaline $\mathrm{H}_{2} \mathrm{O}_{2}$ at room temperature, and stained with $0.05 \%$ trypan blue in lactoglycerol. In the case of maize and clover roots the clearing time was $1 \mathrm{~h}$ and bleaching was omitted. Root colonization by AM fungi was evaluated using the intersection method (McGonigle et al. 1990) at 200× magnification; a minimum of 100 line intersections per subsample of approximately $7 \mathrm{~cm}$ was scored for the presence of AM fungal structures. Approximately $30 \mathrm{~cm}$ of fine roots in total was analyzed for each sample. The results are presented as a percentage of root length colonized (\%RLC).

\section{Statistical analysis}

Statistica 5.1 (StatSoft Inc.) was used for processing and statistical analysis of the data. The plant growth data and concentrations of chemical elements in the soil were subjected to the one-way analysis of variance ANOVA $(p<0.05)$ followed by the Tukey test (all pairwise multiple comparisons). The data were transformed when necessary to achieve normality. The tables and figures present non-transformed data. Non-metric multidimensional scaling was used to compare ECM communities between variants. Distance measures were determined according to the Bray-Curtis method using the PAST 1.89 software (Hammer et al. 2001).

\section{Results}

Experiment 1: effect of mycorrhizal inoculation on ex vitro acclimatization

Survival of the metal-adapted poplar plantlets $(\mathrm{HM}+)$ inoculated with the mycelia of ECM fungi (H. crustuliniforme, P. involutus strains A, B, and C) was higher (up to $100 \%$ ) than 
the plantlets inoculated with the AM fungus $R$. irregularis, and the uninoculated (HM+) and $(\mathrm{HM}-$ ) plantlets (Table 1). There were no significant differences in the shoot and root dry mass among the treatments.

All ECM fungal strains used to inoculate plantlets developed ECMs on poplar fine roots (Fig. 1). Additionally, some root tips were colonized by the ECM fungus Cenococcum geophilum, whose propagules appeared spontaneously in the growth substrate. Relative abundance of ECM morphotypes and non-mycorrhizal root tips in the total pool of poplar fine roots after 8 weeks of acclimatization are shown in Fig. 2. Plantlets inoculated with $H$. crustuliniforme and with the three strains of $P$. involutus had nearly $50 \%$ of their root tips colonized by the fungi used as inoculum; $8-10 \%$ of the root tips were colonized by $C$. geophilum, and the remaining root tips did not form any ECM. In non-inoculated poplar plantlets $\sim 10 \%$ of the root tips were colonized by C. geophilum. Roots of the plantlets inoculated during ex vitro planting with AM inoculum were, after 8 weeks of acclimatization, colonized by the AM fungus, albeit at a low degree $(\sim 3 \%)$. Vesicles and intraradical hyphae were present, but no arbuscules were observed (Fig. 1).

Experiment 2: effect of mycorrhiza on the $\mathrm{Cu}$ - and $\mathrm{Pb}$-treated microplants

The roots of the poplar plantlets cultivated for 16 weeks in non-sterile soil were colonized by various ECM fungi, however no AM structures were found in the root samples. The ECM abundance did not differ significantly according to treatments (metal and ECM fungi) (Fig. I-supplement). Morphotyping and molecular analyses revealed up to six different fungal genera in the poplar roots (Fig. II-supplement). The roots of ECM preinoculated plants dominated by ectomycorrhizas corresponded to fungal species used for inoculation (Hebeloma or Paxillus type) (Fig. III-supplement). The analyses of selected ECM root tips revealed also the presence of mycorrhizas with high similarity to $H$. populinum and $H$. cavipes. Besides, ectomycorrhizas of genera: Cenococcum, Peziza, Tuber and Thelephoraceae were distinguished in the poplar roots (Fig. II, Table II—supplement). Roots of plantlets uninoculated or inoculated with AM fungus $R$. irregularis, were colonized predominantly by the Thelephoraceae fungus. Because of the absence of arbuscular mycorrhiza in the AM pre-inoculated poplars, these plants were not taken under consideration in the further analyses.

The plantlets grown in unpolluted soil and treated for 16 weeks with $\mathrm{Cu}\left(\mathrm{NO}_{3}\right)_{2}$ had decreased leaf biomass (Fig. 3). No negative influence of $\mathrm{Pb}$ on leaf and root biomass was observed (Fig. 3). The poplar microplants pre-inoculated with ECM fungi had higher leaf biomass than the $\mathrm{Cu}$-treated uninoculated plants, although only $P$. involutus-C influenced significantly the stem biomass. Root biomass, length and number of root tips were increased in the microplants grown in the presence of $\mathrm{Pb}$, both inoculated with $P$. involutus-C and uninoculated (Fig. 3).

The plantlets irrigated with the copper nitrate solution accumulated in leaves up to $400 \mathrm{mg} \mathrm{kg}^{-1} \mathrm{Cu}$. Significantly higher $\mathrm{Cu}$ concentration was recorded in leaves of poplars inoculated previously with $H$. crustuliniforme and $P$. involutus strains $\mathrm{B}$ and $\mathrm{C}$ than in leaves of the plants mycorrhizal with autochthonic ECM fungi or pre-inoculated with $P$. involutus strain A. The ECM pre-inoculated plantlets had significantly lower concentration of $\mathrm{Cu}$ in roots than the uninoculated plants (Fig. 4). The plant irrigated with lead nitrate solution accumulated up to $400 \mathrm{mg} \mathrm{kg}^{-1} \mathrm{~Pb}$ in stem, $300 \mathrm{mg} \mathrm{kg}^{-1} \mathrm{~Pb}$ in root and $170 \mathrm{mg} \mathrm{kg}^{-1} \mathrm{~Pb}$ in leaves. Pre-inoculation with $P$. involutus strain $\mathrm{C}$ significantly increased concentration of $\mathrm{Pb}$ in leaves of the poplars when compared to those growing in 
Table 1 Influence of mycorrhizal fungi on the survival and growth of Populus $\times$ canescens microplants

\begin{tabular}{lllc}
\hline Plant origin and mycorrhizal fungi & Shoots mass $(\mathrm{g})$ & Roots mass $(\mathrm{g})$ & Plantlets survival $(\%)$ \\
\hline (HM-) uninoculated & $3.9 \pm 0.7 \mathrm{a}$ & $3.9 \pm 0.6 \mathrm{a}$ & $42.0 \pm 8.1 \mathrm{a}$ \\
(HM+) uninoculated & $4.3 \pm 0.7 \mathrm{a}$ & $4.4 \pm 0.8 \mathrm{a}$ & $63.0 \pm 12.1 \mathrm{ab}$ \\
(HM+) Heb & $5.4 \pm 1.0 \mathrm{a}$ & $5.8 \pm 1.0 \mathrm{a}$ & $100 \pm 0 \mathrm{~b}$ \\
$(\mathrm{HM}+)$ PaxA & $4.9 \pm 0.8 \mathrm{a}$ & $5.4 \pm 0.9 \mathrm{a}$ & $100 \pm 0 \mathrm{~b}$ \\
$(\mathrm{HM}+)$ PaxB & $4.4 \pm 0.8 \mathrm{a}$ & $4.6 \pm 0.8 \mathrm{a}$ & $100 \pm 0 \mathrm{~b}$ \\
$(\mathrm{HM}+)$ PaxC & $4.6 \pm 0.8 \mathrm{a}$ & $4.8 \pm 0.8 \mathrm{a}$ & $100 \pm 0 \mathrm{~b}$ \\
(HM+) BEG 87 & $3.8 \pm 0.7 \mathrm{a}$ & $4.0 \pm 0.7 \mathrm{a}$ & $63.3 \pm 12.1 \mathrm{ab}$ \\
\hline
\end{tabular}

The microplants were derived from in vitro cultures, inoculated with mycorrhizal fungi or remained uninoculated and were cultivated ex vitro for 8 weeks in a growth chamber in unpolluted autoclaved soil mixed with peat $(3: 1, \mathrm{v} / \mathrm{v})$. (HM-), control plants cultivated in vitro in medium without heavy metals; $(\mathrm{HM}+)$, plants with increased tolerance to heavy metals, grown in vitro in media containing $\mathrm{Cu}$ and $\mathrm{Pb}$. Heb, Hebeloma crustuliniforme; PaxA, PaxB, and PaxC, Paxillus involutus strains A, B, and C, respectively; BEG 87, Rhizophagus irregularis, strain BEG 87. Values marked with the same letters within columns do not differ significantly (mean $\pm \mathrm{SE}, p<0.05 ; \mathrm{n}=8$ )

the presence of autochthonic fungi. Concentrations of $\mathrm{Pb}$ in stems and roots did not differ significantly (Fig. 5).

The $\mathrm{Cu}$-treated soil contained 15 -fold more $\mathrm{Cu}$ than the unpolluted soil, while the $\mathrm{Pb}$ treated soil contained up to 120 -fold more $\mathrm{Pb}$ than the control soil. No significant differences were detected in the concentrations of the other mineral elements between the soils treated with $\mathrm{Cu}$ and $\mathrm{Pb}$ and the control soil (Table 2). A significant reduction in the amount of $\mathrm{Cu}$ was identified in soils under plants inoculated with $P$. involutus (strain A, $34.7 \%$; strain B, $29.5 \%$; strain C, $50.7 \%$ ) compared to soil cultivated with uninoculated plants. The plantlets inoculated with $H$. crustuliniforme and $P$. involutus had a small effect on the $\mathrm{Cu}$ concentration in the soil (Table 2).

Experiment 3: effect of mycorrhiza on of poplar microplants grown in soil heavily contaminated with $\mathrm{Cu}$ and $\mathrm{Pb}$ (Głogów copper smelter)

After 16 weeks of cultivation in soil from the vicinity of the copper smelter, the poplar plantlets previously inoculated with mycorrhizal fungi and the uninoculated plants were colonized by ECM fungi, however only significant difference was found between the uninoculated plants and the plants pre-inoculated with $H$. crustuliniforme (Fig. III-supplement). Roots of the plantlets pre-inoculated with $H$. crustuliniforme were dominated by Hebeloma- type mycorrhizas $(65.7 \%)$ and the roots inoculated with $P$. involutus isolates were dominated by Paxillus-type mycorrhizas (49.8-72.3\%) (Fig. IV—supplement). Seven main ECM morphotypes were distinguished by morphotyping in the poplar root samples (Fig. IV-supplement) and nine fungal taxa were identified using molecular analyses of the ECM root samples (Table II-supplement). The indigenous ECM fungal symbionts associated with roots of the plantlets grown in soil from the vicinity of the copper smelter were distinguished as Peziza sp., Hebeloma sp., P. involutus, C. geophillum, a Thelephoraceae species, and two unidentified species.

After 16 weeks of poplars cultivation the concentration of available $\mathrm{Cu}$ in soil ranged between 1,505 and 1,732 $\mathrm{mg} \mathrm{kg}^{-1} \mathrm{~d}$ wt and the concentration of $\mathrm{Pb}$ was $489-67 \mathrm{mg} \mathrm{kg}^{-1}$, depending on the ECM inoculum used for the plant pre-inoculation (Table 3). The polluted soil contained also higher concentrations of other heavy metals ( $\mathrm{Cd}, \mathrm{Fe}, \mathrm{Mn}$, and $\mathrm{Zn}$ ) and 

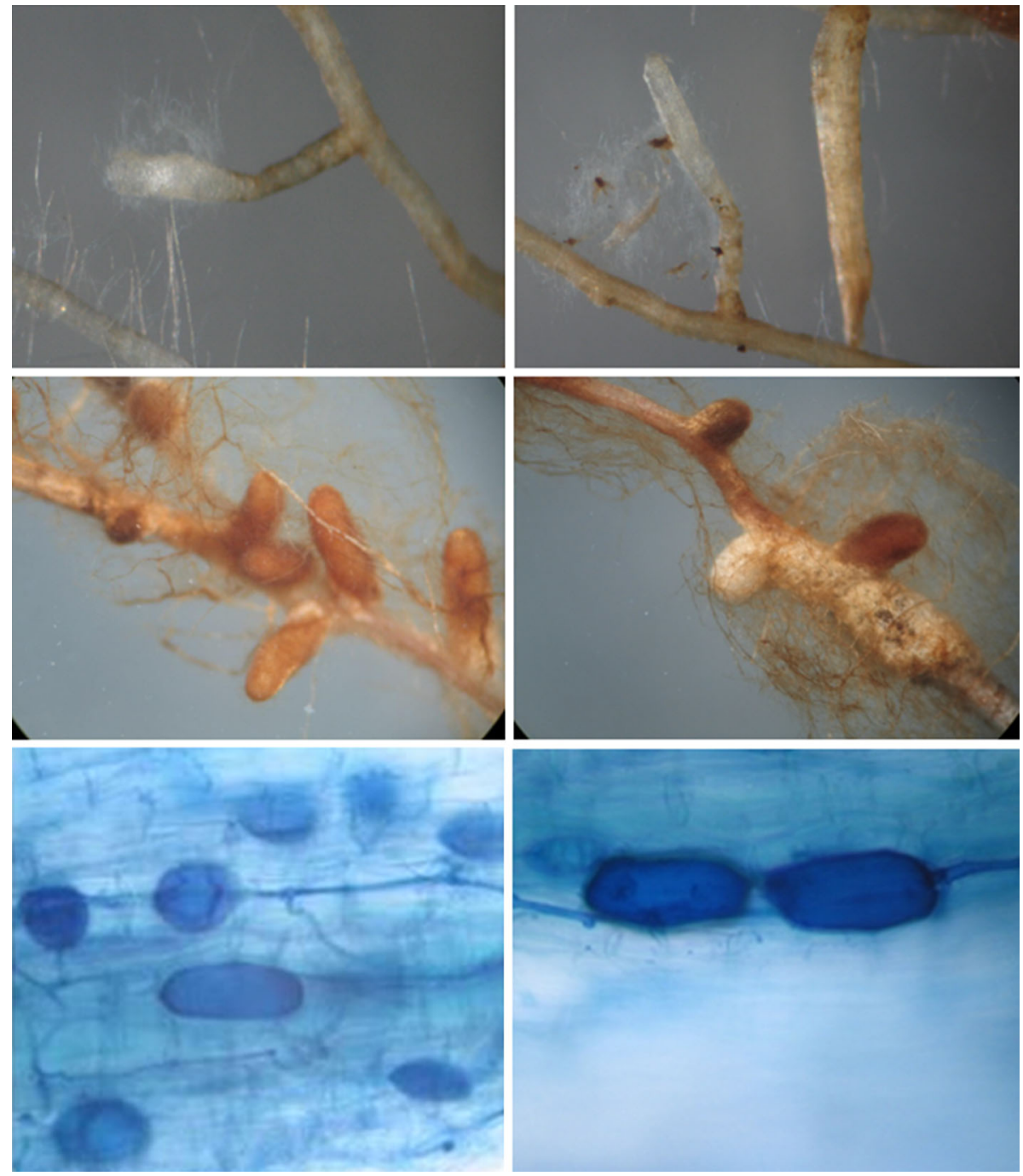

Fig. 1 Ectomycorrhizas of Populus $\times$ canescens plantlets developed by Hebeloma crustuliniforme (top) and Paxillus involutus (middle) and arbuscular mycorrhiza with Rhizophagus irregularis (bottom) after an 8-week acclimatization in a growth chamber in sterilized soil substrate inoculated with the mycorrhizal fungi

lower concentrations of macronutrients $(\mathrm{P}, \mathrm{K}, \mathrm{Mg})$ than the unpolluted control soil. Under poplars inoculated with $H$. crustuliniforme and $P$. involutus strain A, significantly reduced $\mathrm{Cu}$ and $\mathrm{Pb}$ concentrations were recorded: $\mathrm{Cu}$ by $\sim 9-11 \%$, $\mathrm{Pb}$ by $\sim 7-18 \%$, although the reduction in $\mathrm{Pb}$ concentration was not significant (Table 3).

Overall, no significant differences were detected in the biomass of leaves and stems of poplar plantlets regardless treatment (Fig. 6a, b). The root biomass was significantly higher in poplars inoculated with $P$. involutus A (Fig. $6 \mathrm{c}$ ). The plants associated with $P$. involutus strain $\mathrm{B}$, produced higher root length and more root tips than the uninoculated plants grown in the heavily contaminated soil (Fig. 6d, e). 


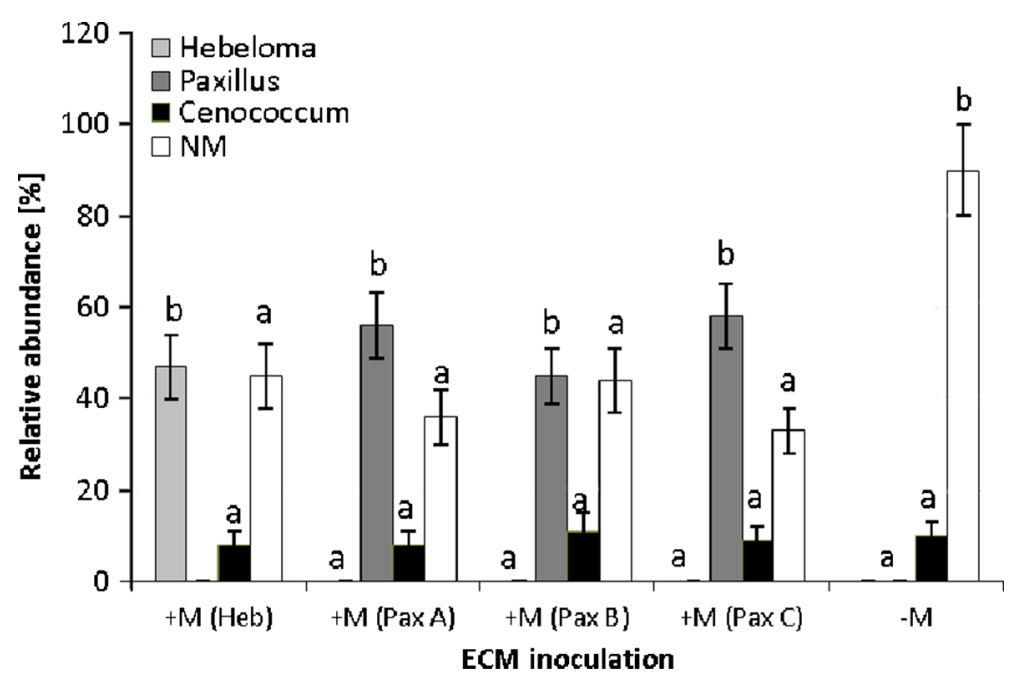

Fig. 2 Relative abundance (\%) of ECM root tips colonized by Hebeloma crustuliniforme (Heb), Paxillus involutus (PaxA, PaxB, PaxC), and Cenococcum geophilum as well as non-mycorrhizal (NM) root tips in the roots of Populus $\times$ canescens plantlets after 8 weeks of acclimatization in a growth chamber. Soils were uninoculated $(-M)$ or inoculated with the indicated fungus $(n=7)$

Non-metric multidimensional scaling indicated similarities and differences between the ECM communities from poplars after 16 weeks of post-acclimatization growth in unpolluted and metal-polluted soils (Fig. V-supplement). ECM communities from poplars inoculated with three $P$. involutus strains and grown in soil treated with $\mathrm{Cu}\left(\mathrm{NO}_{3}\right)_{2}$ and ECM communities from poplars inoculated with $P$. involutus strains and grown in soil taken from Głogów formed two tight groups that were separated from each other, from the ECM communities of uninoculated plants, and from the ECM communities of plants inoculated with $H$. crustuliniforme grown in $\mathrm{Cu}$-treated soil and in soil from the vicinity of the copper smelter.

The poplars grown in the soil taken from the vicinity of the copper smelter accumulated higher amounts of $\mathrm{Cu}$ and $\mathrm{Pb}$ in roots than in stems and leaves (Fig. 7). The concentration of $\mathrm{Cu}$ in leaves of the poplars grown in the metal-contaminated soil was significantly higher in the case of plants pre-inoculated with $H$. crustuliniforme than in uninoculated plants (55 and $45 \mathrm{mg} \mathrm{kg}^{-1}$ ), and significantly lower in $P$. involutus inoculated plants $\left(28 \mathrm{mg} \mathrm{kg}^{-1}\right)$ (Fig. 7a). The poplar stems of $H$. crustuliniforme inoculated plants contained lower $\mathrm{Cu}$ than the uninoculated plants (Fig. 7b). The poplar roots had 7-10 times higher $\mathrm{Cu}$ concentration than the leaves. Roots of the poplars inoculated with $P$. involutus strain $\mathrm{C}$ had significantly higher $\mathrm{Cu}$ concentration than roots of plants inoculated with $P$. involutus A and B (Fig. 7c). The highest concentration of $\mathrm{Pb}$ was recorded in stems of uninoculated poplars $\left(74 \mathrm{mg} \mathrm{kg}^{-1}\right)$ (Fig. 7). The ECM-inoculated poplars had higher $\mathrm{Pb}$ concentration in leaves than the uninoculated plants and significantly lower concentration in stems (Fig. 7).

\section{Discussion}

Results of this study confirmed our expectation that mycorrhizal associations would enhance the survival and growth of selected $\mathrm{Cu}$ - and $\mathrm{Pb}$-tolerant lines of grey poplar and 

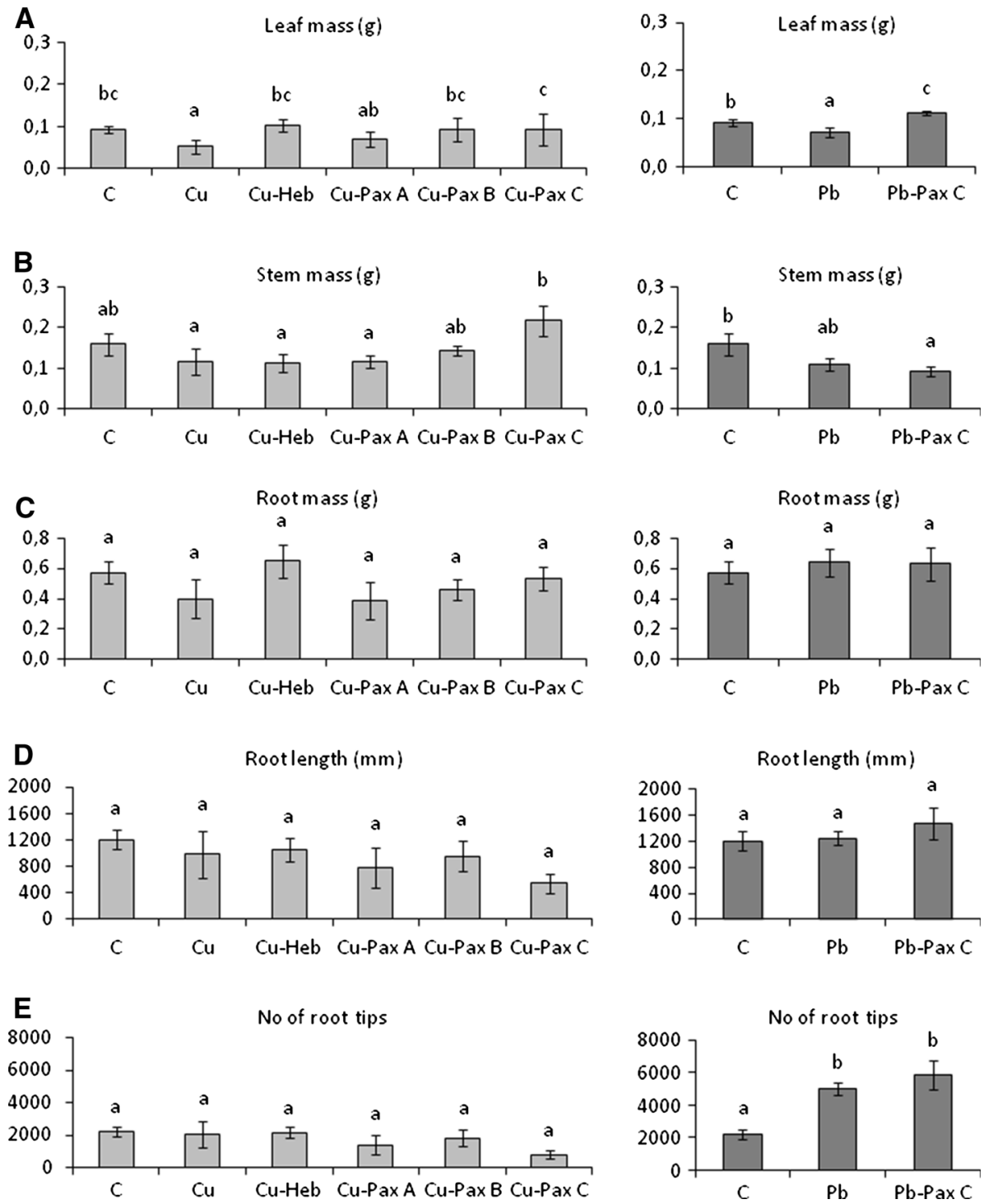

Fig. 3 Growth parameters of Populus $\times$ canescens plantlets grown for 16 weeks in a greenhouse in unpolluted, unsterilized soil mixed with peat $\left(3: 1\right.$ v/v) treated with $\mathrm{Cu}\left(\right.$ as $\left.\mathrm{Cu}\left(\mathrm{NO}_{3}\right)_{2} \cdot 3 \mathrm{H}_{2} \mathrm{O}\right)$ or $\mathrm{Pb}(\mathrm{as}$ $\left.\mathrm{Pb}\left(\mathrm{NO}_{3}\right)_{2}\right)$. The plants were pre-inoculated with Hebeloma crustuliniforme (Heb), Paxillus involutus (PaxA, PaxB, PaxC) or remained uninoculated. Control soil (C) was not treated with heavy metals. Data are mean $\pm \mathrm{SE}$. Values marked with the same letters are not significantly different $(p=0.05 ; n=7)$

improve their ability to colonize and clean up heavily metal-contaminated soils. Similarly, in vitro culture has been used previously for selection of Al-tolerant grey poplar microplants (Bojarczuk 2004b), and Al/Cu-tolerant silver birch microplants (Bojarczuk and Szczygieł 2004). ECM fungi (H. crustuliniforme and $P$. involutus) developed ectomycorrhizas with $P . \times$ canescens microplants in vitro within 2-3 week after inoculation (data 


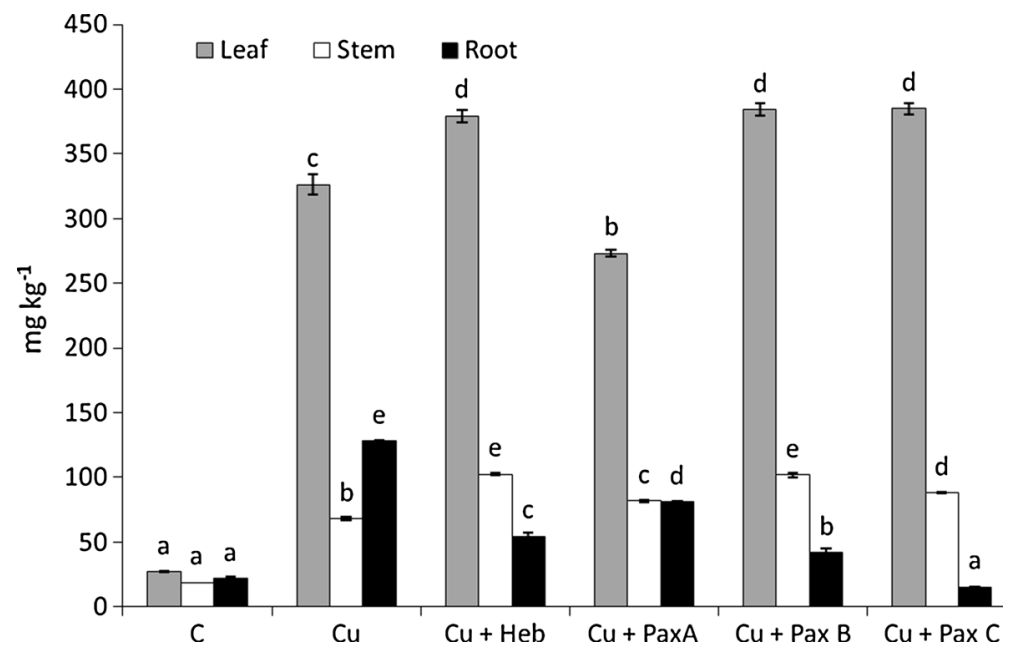

Fig. 4 Concentration of $\mathrm{Cu}$ in leaf, stem and roots of Populus $\times$ canescens plantlets grown for 16 weeks in a greenhouse in unpolluted, unsterilized soil mixed with peat $(3: 1 \mathrm{v} / \mathrm{v})$ and treated with $\mathrm{Cu}\left(\right.$ as $\mathrm{Cu}\left(\mathrm{NO}_{3}\right)_{2-}$ $3 \mathrm{H}_{2} \mathrm{O}$ ) or in control soil (C) not treated with $\mathrm{Cu}$. The plants were pre-inoculated with Hebeloma crustuliniforme (Heb), Paxillus involutus (PaxA, PaxB, PaxC) or remained uninoculated. Data are mean $\pm \mathrm{SE}$. Values marked with the same letters are not significantly different $(p=0.05 ; n=3)$

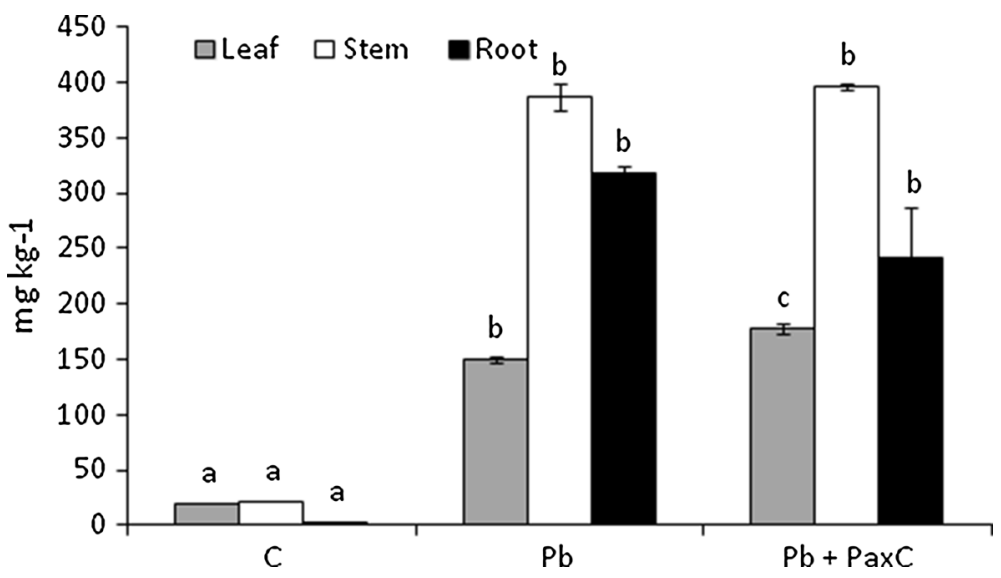

Fig. 5 Concentration of $\mathrm{Pb}$ in leaf, stem and roots of Populus $\times$ canescens plantlets grown for 16 weeks in a greenhouse in unpolluted, unsterilized soil mixed with peat $(3: 1 \mathrm{v} / \mathrm{v})$ and treated with $\mathrm{Pb}\left(\mathrm{as} \mathrm{Pb}\left(\mathrm{NO}_{3}\right)_{2}\right)$ or in control soil $(\mathrm{C})$ not treated with $\mathrm{Pb}$. The plants were pre-inoculated with Paxillus involutus $(\mathrm{PaxC})$ or remained uninoculated. Data are mean \pm SE. Values marked with the same letters are not significantly different $(p=0.05 ; n=3)$

not shown). Ex vitro inoculation of the grey poplar microplants resulted in abundant ectomycorrhizas (Figs. 1,2) and enhanced survival of the plantlets during ex vitro acclimatization (Table 1). Colonization of a low percentage of root tips with ECM fungus Cenococcum geophilum can be caused by propagules of the fungus present in the unsterilized peat-component of growth media used in our experiments. Under natural conditions, $H$. crustuliniforme and $P$. involutus develop ECM symbiosis with a wide 


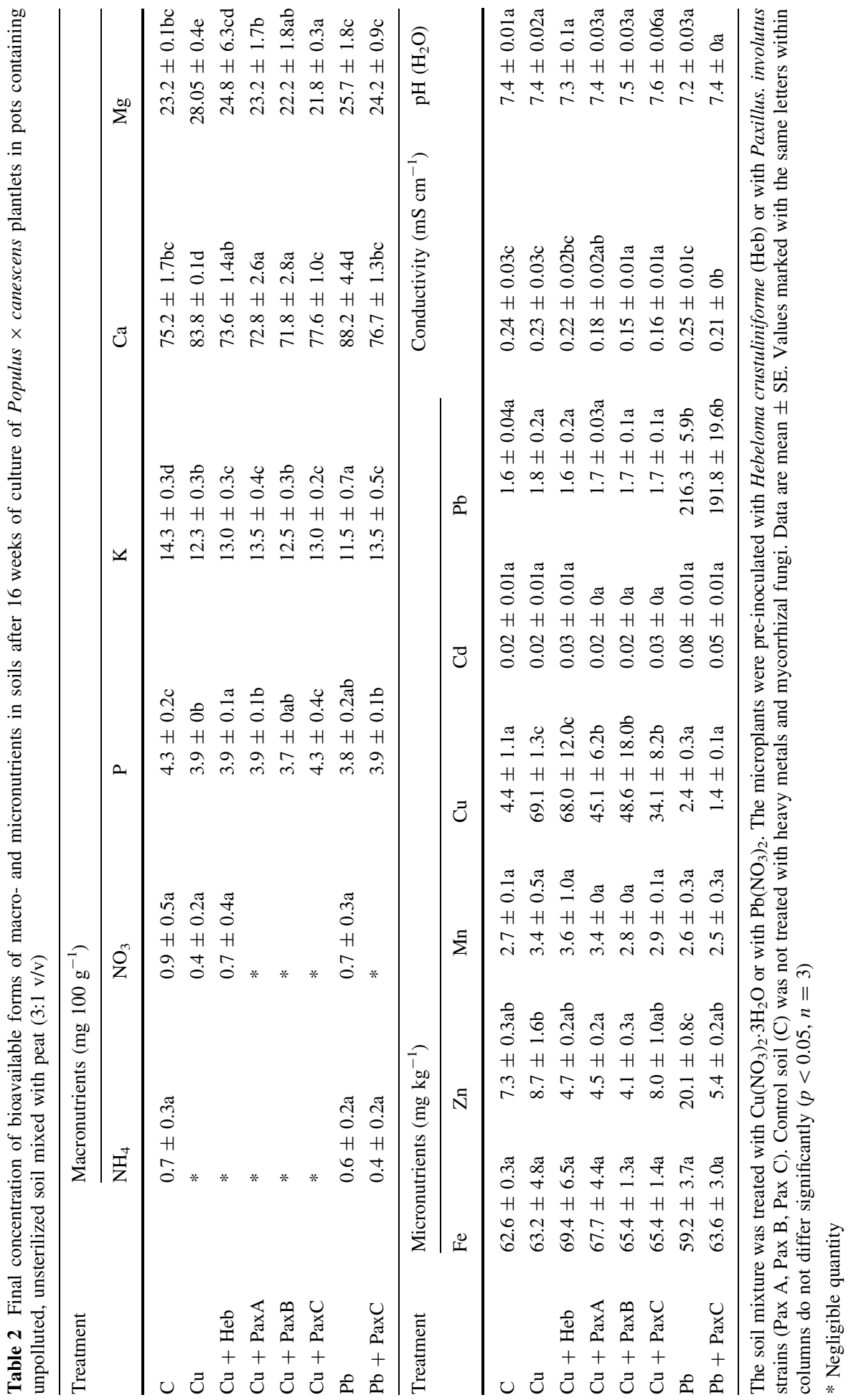




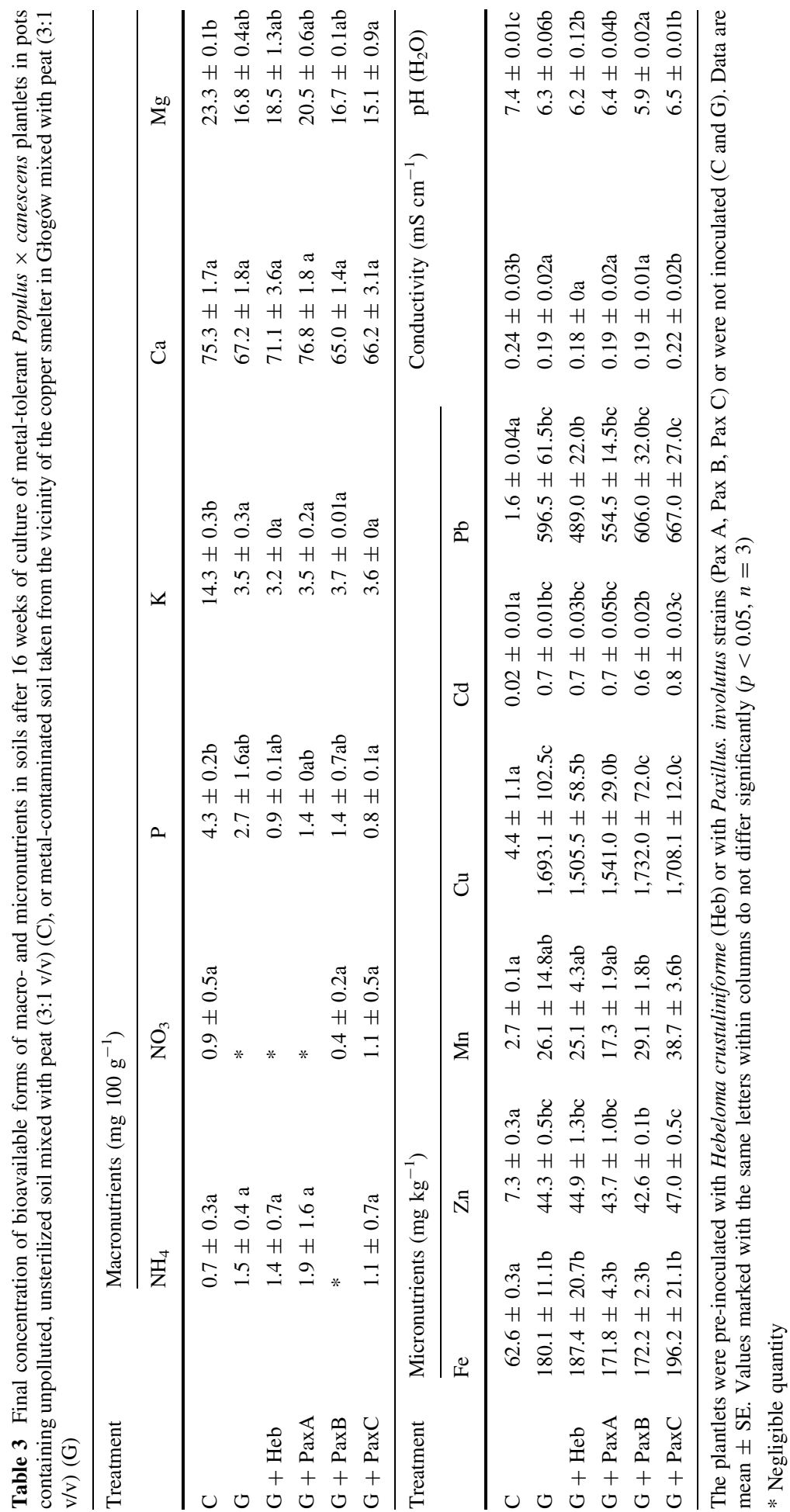



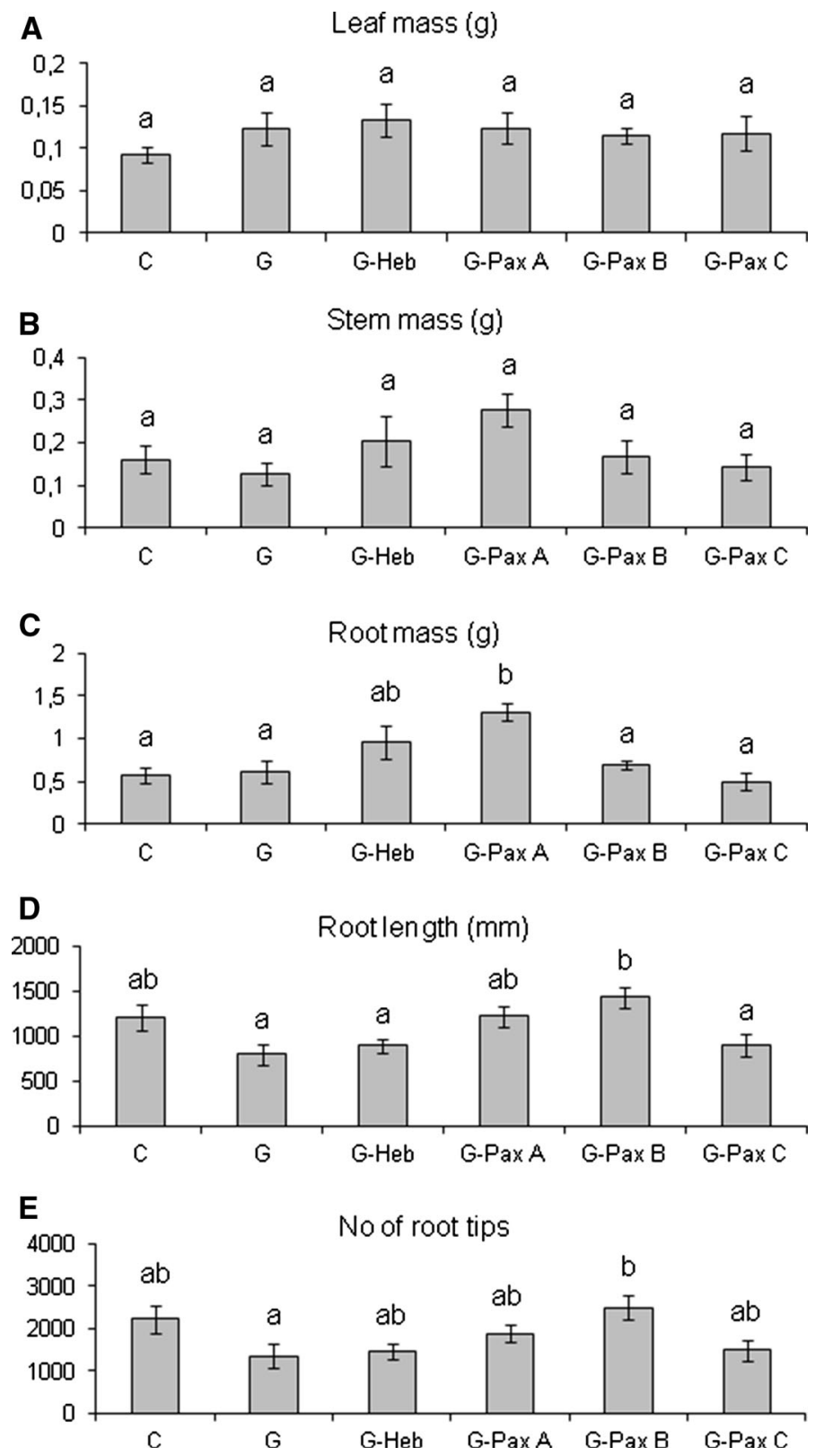

Fig. 6 Growth parameters of Populus $\times$ canescens microplants grown for 16 weeks in polluted soil collected from the vicinity of a copper smelter in Głogów $(G)$ or in unpolluted soil $(C)$. Soil were mixed with peat $(3: 1, \mathrm{v} / \mathrm{v})$. The plants were pre-inoculated with Hebeloma crustuliniforme (Heb), Paxillus involutus strains (PaxA, PaxB, PaxC) or remained uninoculated. Data are mean \pm SE. Values marked with the same letters are not significantly different $(p=0.05 ; n=7)$

spectrum of deciduous and coniferous species (Cairney and Chambers 1999). P. involutus have been identified as the most effective ECM symbiont of micropropagated Populus deltoides, significantly enhancing the plant growth, while other fungi (C. geophilum, 

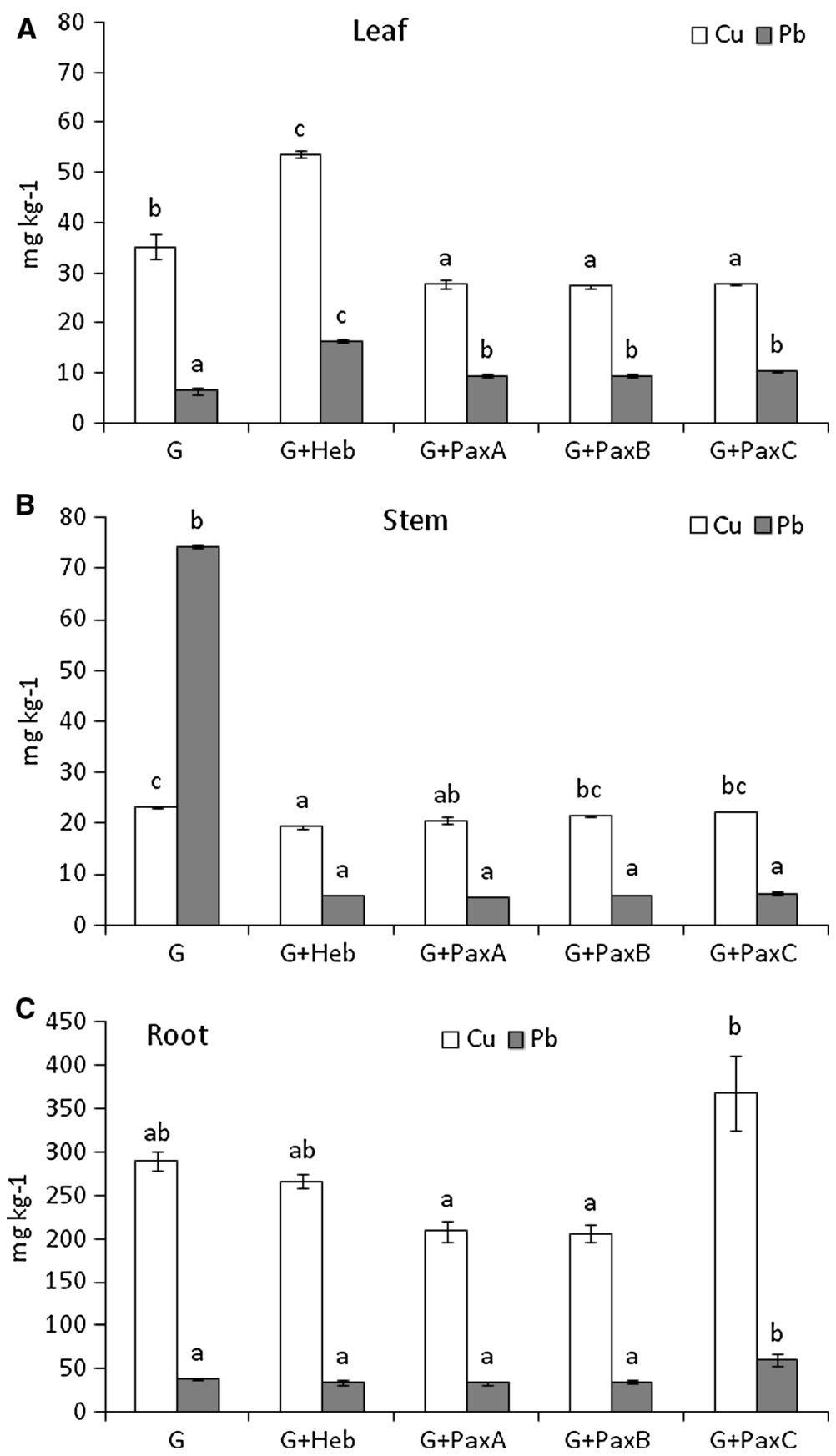

Fig. 7 Concentration of $\mathrm{Cu}$ and $\mathrm{Pb}$ in leaf, stem and roots of Populus $\times$ canescens plantlets grown for 16 weeks in a greenhouse in polluted soil collected from the vicinity of a copper smelter in Głogów (G) or in unpolluted soil (C). Soils were mixed with peat $(3: 1, \mathrm{v} / \mathrm{v})$. The plants were previously-inoculated with Hebeloma crustuliniforme (Heb), Paxillus involutus strains (PaxA, PaxB, PaxC) or remained uninoculated. Data are mean $\pm \mathrm{SE}$. Values marked with the same letters are not significantly different $(p=0.05 ; n=3)$ 
Laccaria laccata, and Pisolithus tinctorius) did not form ECM structures with $P$. deltoides roots, although they colonized extensively the growth medium (Reddy and Satyanarayana 1998). Selected strains of $P$. involutus used for inoculation of $P . \times$ canescens microplants enhanced tolerance of the poplar plants to salt stress (Langenfeld-Heyser et al. 2007; Li et al. 2012), drought stress (Luo et al. 2009b), and cadmium toxicity (Ma et al. 2014).

Although Populus spp. and hybrids are considered as dual mycorrhizal plants, contradictory results have been reported in the literature. Some authors suggested that AM is dominant in young poplars and ECM is prevalent in older Populus plants. Such findings reported Aguillon and Garbaye (1990) who found that 5-month-old P. × euramericana, clone I-214, inoculated with ECM fungus $P$. involutus and/or AM fungus Glomus mosse had higher level of AM than ECM colonization. Todeschini et al. (2007) reported that cuttings of $P$. alba and $P$. nigra clones planted in sterilized soil, inoculated with AM fungi and after 40 days transplanted to unsterilized soil, revealed after 6 months variable levels of AM colonization ( $P$. alba 7-12\%, P. nigra 15-50\%), but they had no ECM. We demonstrated that the young $P . \times$ canescens plants have a higher predisposition for ECM than AM association. Low colonization (3\% RLC) of the plantlets by the AM fungus, versus 50-60\% ECM colonization (Fig. I-supplement), and the fact that the poplar plantlets after 16 weeks of cultivation in unsterilized soils were exclusively ECM, are proof of this (Figs. II, III-supplement). Increasing amount of data indicate the influence of host plant genotype on AM/ECM colonization. Khasa et al. (2002) investigated 28 Populus clones grown in a 5-year-old plantation and found that ECM fungi dominated in roots of most of the clones, colonizing 35-90\% of root tips, whereas AM colonization ranged between 20 and $50 \%$. Rachwał et al. (2003) observed the ECM/AM ratio in roots of 15 Populus clones cultivated from cuttings in pots for one growing season and found 8 of the clones dominated by AM (10-40\% RLC) with low ECM colonization ( $<5 \%$ RLC), 6 clones dominated by ECM (50-90 \% RLC) and one clone exclusively ECM. Comparison of ECM/AM colonization of four poplar hybrids grown under three different environments and three rooting depth (Karlinski et al. 2010) confirmed the dependence of the mycorrhizal status on poplar genotype and indicated a significant impact of soil contamination with heavy metals and soil depth on the ECM/AM proportion. Our results revealed that $P . \times$ canescens benefits from ectomycorrhiza. Similarly, significant positive influence on tolerance of this poplar hybrid to toxic substances in soil reported Langenfeld-Heyser et al. 2007; Li et al. 2012; Luo et al. 2009b; Ma et al. 2014. The type of ECM fungus used for pre-inoculation determined variability of ECM communities of the poplars (Fig. Vsupplement).

In this study the selected clone of $P . \times$ canescens accumulated increased amounts of $\mathrm{Cu}$ and $\mathrm{Pb}$ when grown in metal-contaminated soils (Figs. 4, 5, 7). $\mathrm{Cu}$ was allocated to the leaves when plants were grown at lower concentration of $\mathrm{Cu}$ ions, regularly supplied with solution ( $\mathrm{pH} 4.5$ ) containing not high, but well available $\mathrm{Cu}$ (Fig. 4), and was accumulated mostly in roots of poplars grown in soil heavily contaminated with $\mathrm{Cu}$ and $\mathrm{Pb}$ (soil from the vicinity of the copper smelter) (Fig. 7; Table I-supplement). The mobility of metals in soil and their accumulation in plants depends on the metal, on plant genotype and the soil conditions, such as $\mathrm{pH}$, organic matter content, and ion exchange capacity. Therefore usually the concentration of a metal in plants is not related to the concentration of the metal in soil (Kabata-Pendias and Pendias 2001). Restriction of Cu mobility and its accumulation mostly in plant roots was also reported by Baker and Brooks (1989) and Kopponen et al. (2001). Polle et al. (2013) found that $P$. $\times$ canescens accumulated higher amounts of $\mathrm{Cd}$ in roots and $P . \times$ euphratica in leaves. Pre-inoculation of the $P . \times$ canescens microplants with ECM fungi $H$. crustuliniforme and $P$. involutus enhanced accumulation of $\mathrm{Cu}$ and $\mathrm{Pb}$ in 
the poplar leaves (Figs. 4, 5). In the heavily contaminated soil only the plantlets pre-inoculated with $H$. crustuliniforme accumulated higher level of $\mathrm{Cu}$ in leaves (Fig. 7). Ma et al. (2014) indicated that ectomycorrhiza with $P$. involutus enhanced concentration of $\mathrm{Cd}$ in leaves, bark, wood and roots of $P . \times$ canescens and increased tolerance of the poplar to $\mathrm{Cd}$.

The key benefit of ECM inoculation of the poplar plantlets in the present research seems to be the enhancement of the plant tolerance to heavy metals. The microplants were able to survive for 16 weeks in the soil contaminated with available $\mathrm{Cu}$ and $\mathrm{Pb}$ (Table $\mathrm{I}$ - supplement) in concentrations that exceeded 22 times and 7 times, respectively, the maximal allowable limits in Poland and other countries (Kabata-Pendias 1995). Furthermore, $P . \times$ canescens microplants inoculated with selected ECM fungi have an improved potential to reduce concentration of $\mathrm{Cu}$ and $\mathrm{Pb}$ (Tables 2, 3). Within 16 weeks of growth, $\mathrm{Cu}$ concentrations in the soil from the vicinity of the copper smelter were reduced by 7-18\% (120-300 mg Cu kg ${ }^{-1}$ dry weight of soil) under the plantlets inoculated with $H$. crustuliniforme and PaxA, compared to the soil under non-inoculated poplars. The $\mathrm{Pb}$ reduction in the soil under plantlets inoculated with $H$. crustuliniforme $(18 \% ; 82 \mathrm{mg} \mathrm{Pb}$ $\mathrm{kg}^{-1}$ dry weight of soil) was more pronounced than under plants inoculated with $P$. involutus strains and under the uninoculated plants (0-7 \%; Table 3). Mycorrhizal fungi may contribute to the protection of the host plant against toxic metals by a variety of mechanisms. An important mechanism is the enhanced uptake of water and nutrients by the fungal extramatrical hyphae, improving the plant water relations and plant nutrition (Luo et al. 2009b; Beniwal et al. 2010). Fungi are able to accumulate significant amounts of heavy metals (Gadd 1993) and to detoxify the metal ions via metal chelation by cysteinerich peptides such as reduced glutathione, phytochelatins, and metallothioneins (Blaudez et al. 2000). Our previous study revealed accumulation of high concentrations of $\mathrm{Cu}$ and $\mathrm{Pb}$ in ECM roots of birch seedlings and reduction of the heavy metals concentration in stems and leaves (Bojarczuk and Kieliszewska-Rokicka 2010). P. involutus has been shown to produce $\mathrm{Cu}$-metallothionein; its production was correlated with the tolerance to $\mathrm{Cu}$ (Howe et al. 1997). We can expect that extramatrical mycelium could have a role in reduction of $\mathrm{Cu}$ and $\mathrm{Pb}$ availability in the metal-contaminated soils and uptake by $P . \times$ canescens.

In conclusion, in vitro plant propagation makes it possible to produce a large number of plants with tolerance to heavy metals. This study revealed that in vitro selection of poplar plantlets tolerant to toxic $\mathrm{Cu}$ and $\mathrm{Pb}$ ions and their biotization using appropriate ECM fungi can facilitate plant acclimatization, may increase plant tolerance of biotic and abiotic stresses, and contributes to better plant growth under stressful conditions. Inoculation of young poplar plants with mycorrhizal fungi may enhance their potential for bioremediation of soils contaminated with toxic metals.

Acknowledgments This work was financially supported by the National Science Center, Poland (Grant No. NN 309296543) and by the Institute of Dendrology (statutory project).

Open Access This article is distributed under the terms of the Creative Commons Attribution License which permits any use, distribution, and reproduction in any medium, provided the original author(s) and the source are credited.

\section{References}

Aguillon RL, Garbaye J (1990) Some aspects of a double symbiosis with ectomycorrhizal and VAM fungi. Agric Ecosyst Environ 29:263-266

Baker AJM, Brooks RR (1989) Terrestrial higher plants which hyperaccumulate metallic elements: a review of their distribution, ecology and phytochemistry. Biorecovery 1:81-126 
Baldrian P (2009) Ectomycorrhizal fungi and their enzymes in soils: is there enough evidence for their role as facultative spoil saprotrophs? Oecologia 161:657-660

Balsberg-Påhlsson AM (1989) Toxicity of heavy metals (Zn, Cu, Cd, Pb) to vascular plants. Water Air Soil Pollut 47:287-319

Beniwal RS, Langenfeld-Heyser R, Polle A (2010) Ectomycorrhiza and hydrogel protect hybrid poplar from water deficit and unravel plastic responses of xylem anatomy. Environ Exp Bot 69:189-197

Bissonnette L, St-Arnaud M, Labrecque M (2010) Phytoextraction of heavy metals by two Salicaceae clones in symbiosis with arbuscular mycorrhizal fungi during the second year of a field trial. Plant Soil 332:55-67

Blaudez D, Jacob C, Turnau K, Colpaert JV, Ahonen-Jonnarth U, Finlay R, Botton B, Chalot M (2000) Differential responses of ectomycorrhizal fungi to heavy metals in vitro. Mycol Res 104:1366-1371

Bojarczuk K (2004a) Effect of toxic metals on the development of poplar (Populus tremula L. $\times$ P. alba L.) cultured in vitro. Pol J Environ Stud 13:115-120

Bojarczuk K (2004b) Effect of aluminium on the development of poplar (Populus tremula L. $\times$ P. alba L.) in vitro and in vivo. Pol J Environ Stud 13:261-266

Bojarczuk K, Kieliszewska-Rokicka B (2010) Effect of ectomycorrhiza on $\mathrm{Cu}$ and $\mathrm{Pb}$ accumulation in leaves and roots of silver birch (Betula pendula Roth.) seedlings growth in metal-contaminated soil. Water Air Soil Pollut 207:227-240

Bojarczuk K, Szczygieł K (2004) Effect of aluminium and copper on the development of birch (Betula pendula Roth.) cultured in vitro and in vivo. Dendrobiology 51:3-8

Borghi M, Tognetti R, Monteforti G, Sebastiani L (2007) Responses of Populus $\times$ euramericana (P. deltoides $\times$ P. nigra) clone Adda to increasing copper concentration. Environ Exp Bot 61:66-73

Bothe H, Turnau K, Regvar M (2010) The potential role of arbuscular mycorrhizal fungi in protecting endangered plants and habitats. Mycorrhiza 20:445-457

Cairney JWG, Chambers SM (eds) (1999) Ectomycorrhizal fungi, key genera in profile. Springer, Berlin

Cicatelli A, Todeschini V, Lingua G, Torrigiani P, Castiglione S (2014) Epigenetic control of heavy metal stress response in mycorrhizal versus non-mycorrhizal poplar plants. Environ Sci Pollut Res 21:1723-1737

Durand TC, Baillif P, Albe'Ric P, Carpin S, Label P, Hausman J-F, Morabito D (2011) Cadmium and zinc are differentially distributed in Populus tremula $\times P$. Alba exposed to metal excess. Plant Biosyst $145: 397-405$

Gadd GM (1993) Interactions of fungi with toxic metals. New Phytol 124:25-60

Gafur A, Schutzendubel A, Langenfeld-Heyser R, Fritz E, Polle A (2004) Compatible and incompetent Paxillus involutus isolates for ectomycorrhiza formation in vitro with poplar (Populus $\times$ canescens) differ in $\mathrm{H}_{2} \mathrm{O}_{2}$ production. Plant Biol 6:91-99

Gardes M, Bruns TD (1996) Community structure of ectomycorrhizal fungi in a Pinus muricata forest: above- and below-ground views. Can J Bot 74:1572-1583

Gehring CA, Mueller C, Whitham TG (2006) Environmental and genetic effects on the formation of ectomycorrhizal and arbuscular mycorrhizal associations in cottonwoods. Oecologia 149:158-164

Hammer $\varnothing$, Harper DAT, Ryan PD (2001) PAST: paleontological statistics software package for education and data analysis. Palaeontol Electron 4:9

Hampp R, Ecke M, Schaeffer C, Wallenda T, Wingler A, Kottke I, Sundberg B (1996) Axenic mycorrhization of wild type and transgenic hybrid aspen expressing T-DNA indoleacetic acid-biosynthetic genes. Trees 11:59-64

He JL, Li H, Luo J, Ma CF, Li SJ, Qu L, Gai Y, Jiang XN, Janz D, Polle A, Tyree M, Luo ZB (2013) A transcriptomic network underlies microstructural and physiological responses to cadmium in Populus $\times$ canescens. Plant Physiol 162:424-439

Hildebrandt U, Regvar M, Bothe H (2007) Arbuscular mycorrhiza and heavy metal tolerance. Phytochemistry 68:139-146

Howe R, Evans RL, Ketteridge SW (1997) Copper-binding proteins in ectomycorrhizal fungi. New Phytol 135:123-131

Joner EJ, Briones R, Leyval C (2000) Metal-binding capacity of arbuscular mycorrhizal mycelium. Plant Soil 226:227-234

Kabata-Pendias A (1995) Agricultural problems related to excessive trace metal contents of soil. In: Salomons W, Förstner U, Mader P (eds) Heavy metals (problems and solutions). Springer, Berlin, pp 3-18

Kabata-Pendias A, Pendias H (2001) Trace elements in soil and plants, 3rd edn. CRC, Boca Raton

Karliński L, Rudawska M, Kieliszewska-Rokicka B, Leski T (2010) Relationship between genotype and soil environment during colonization of poplar roots by mycorrhizal and endophytic fungi. Mycorrhiza 20:315-324 
Khasa PD, Chakravarty P, Robertson A, Thomas BR, Dancik BP (2002) The mycorrhizal status of selected poplar clones introduced in Alberta. Biomass Bioenerg 22:99-104

Komosa A, Szewczuk A (2002) Effect of soil potassium level and different potassium fertilizer forms on nutritional status, growth and yield of apple trees in the first three years after planting. J Fruit Ornam Plant Res 19:41-54

Kopponen P, Utriainen M, Lukkari K, Suntioinen S, Karenlampi L, Karenlampi S (2001) Clonal differences in copper and zinc tolerance of birch in metal supplemented soils. Environ Pollut 112:89-97

Kormanik PP, McGraw AC (1982) Quantification of vesicular-arbuscular mycorrhizae in plant roots. In: Schenck NC (ed) Methods and principles of mycorrhizal research. Am Phytopathol Soc, St. Paul, pp 37-45

Krzaklewski W, Barszcz W, Małek S, Kozioł K, Pietrzykowski M (2004) Contamination of forest soil in the vicinity of the sedimentation pond after zinc and lead ore flotation (in the region of Olkusz, southern Poland). Water Air Soil Pollut 159:151-164

Langenfeld-Heyser R, Gao J, Ducic T, Tachd P, Lu CF, Fritz E, Gafur A, Polle A (2007) Paxillus involutus mycorrhiza attenuate $\mathrm{NaCl}$-stress responses in the salt-sensitive hybrid poplar Populus $\times$ canescens. Mycorrhiza 17:121-131

Langer I, Krpata D, Peintner U, Wenzel WW, Schweiger P (2008) Media formulation influences in vitro ectomycorrhizal synthesis on the European aspen Populus tremula L. Mycorrhiza 18:297-307

Leski T, Aucina A, Skridaila A, Pietras M, Riepsas E, Rudawska M (2010) Ectomycorrhizal community structure of different genotypes of Scots pine under forest nursery conditions. Mycorrhiza 20:473-481

Li J, Bao S, Zhang Y, Ma X, Mishra-Knyrim M, Sun J, Sa G, Shen X, Polle A, Chen S (2012) Paxillus involutus strains MAJ and NAU mediate $\mathrm{K}(+) / \mathrm{Na}(+)$ homeostasis in ectomycorrhizal Populus $\times$ canescens under sodium chloride stress. Plant Physiol 159:1771-1786

Lindsay WL, Norvell WA (1978) Development of DTPA soil test for zink, iron, manganese, and cooper. Soil Sci Soc Am J 42:421-428

Loewe A, Einig W, Shi L, Dizengremel P, Hampp R (2000) Mycorrhiza formation and elevated $\mathrm{CO}_{2}$ both increase the capacity for sucrose synthesis in source leaves of spruce and aspen. New Phytol 145:565-574

Luna CM, González CA, Trippi VS (1994) Oxidative damage caused by an excess of copper in oat leaves. Plant Cell Physiol 35:11-15

Luo ZB, Janz D, Jiang XN, Gobel C, Wildhagen H, Tan YP, Rennenberg H, Feussner I, Polle A (2009a) Upgrading root physiology for stress tolerance by ectomycorrhizas: insights from metabolite and transcriptional profiling into re-programming for stress anticipation. Plant Physiol 151:1902-1917

Luo ZB, Li K, Jiang X, Polle A (2009b) Ectomycorrhizal fungus (Paxillus involutus) and hydrogels affect performance of Populus euphratica exposed to drought stress. Ann For Sci 66:106 $\mathrm{p}_{1}-106_{\mathrm{p} 10}$

Luo ZB, Li K, Gai Y, Gobel C, Wildhagen H, Jiang XN, Feussner I, Rennenberg H, Polle A (2011) The ectomycorrhizal fungus (Paxillus involutus) modulates leaf physiology of poplar towards improved salt tolerance. Environ Exp Bot 72:304-311

Luo ZB, Wu C, Zhang C, Li H, Lipka U, Polle A (2014) The role of ectomycorrhizas in heavy metal stress tolerance of host plants. Environ Exp Bot 108:47-62. doi:10.1016/j.envexpbot.2013.10.018

Ma YL, He JL, Ma CF, Luo J, Li H, Liu TX, Polle A, Peng CH, Luo ZB (2014) Ectomycorrhizas with Paxillus involutus enhance cadmium uptake and tolerance in Populus $\times$ canescens. Plant Cell Environ 37:627-642

McGonigle TP, Miller MH, Evans DG, Fairchild GL, Swan JA (1990) A new method, which gives an objective measure of colonization of roots by vesicular-arbuscular mycorrhizal fungi. New Phytol 115:495-501

Medynska-Juraszek A, Kabała C (2012) Heavy metal pollution of forest soils affected by the copper industry. J Elem 17:441-451. doi:10.5601/jelem.2012.17.3.07

Merrild MP, Ambus P, Rosendahl S, Jakobsen I (2013) Common arbuscular mycorrhizal networks amplify competition for phosphorus between seedlings and established plants. New Phytol 200:229-240

Migeon A, Richaud P, Guinet F, Chalot M, Blaudez D (2009) Metal accumulation by woody species on contaminated sites in the north of France. Water Air Soil Pollut 204:89-101

Murashige T, Skoog F (1962) A revised medium for rapid growth and bio-assays with tobacco tissue cultures. Physiol Plant 15:473-497

Nehnevajova E, Herzig R, Erismann K, Schwitzguébel J-P (2007) In vitro breeding of Brassica juncea L. to enhance metal accumulation and extraction properties. Plant Cell Rep 26:429-437

Ott T, Fritz E, Polle A, Schützendübel A (2002) Characterisation of antioxidative systems in the ectomycorrhiza-building basidiomycete Paxillus involutus (Bartsch) Fr and its reaction to cadmium. FEMS Microbiol Ecol 42:359-366 
Pachlewski R, Pachlewska J (1974) Studies on symbiotic properties of mycorrhizal fungi of pine (Pinus sylvestris L.) with the aid of the method of mycorrhizal synthesis in pure cultures on agar. IBL, Warszawa

Pennanen T, Frostegard A, Fritze H, Bååth E (1996) Phospholipid fatty acid composition and heavy metal tolerance of soil microbial communities along two heavy metal-polluted gradients in coniferous forests. Appl Environ Microbiol 62:420-428

Polle A, Klein T, Kettner C (2013) Impact of cadmium on young plants of Populus euphratica and $P$. $\times$ canescens, two poplar species that differ in stress tolerance. New For 44:13-22

Pourrut B, Shahid M, Dumat C, Winterton P, Pinelli E (2011) Lead uptake, toxicity, and detoxification in plants. Rev Environ Contam Toxicol 213:113-136

Rachwał L, Figaj J, Stobiecki S, Kieliszewska-Rokicka B (2003) Phytoremediation of soil and groundwater contaminated with pesticides: potential use of poplar clones. In: Proceedings of the sixth international symposium and exhibition on environmental contamination in central and eastern Europe and the commonwealth of independent states, Prague 1-4.09.2003, http://www.prague2003.fsu.edu/content/ index.htm, pp 179-183

Reddy MS, Satyanarayana T (1998) Ectomycorrhizal formation in micropropagated plantlets of Populus deltoides. Symbiosis 25:343-348

Rudawska M, Leski T (2005) Trace element in fruiting bodies of ectomycorrhizal fungi growing in Scots pine (Pinus sylvestris L.) stands in Poland. Sci Total Environ 339:103-115

Smith SE, Read DJ (2008) Mycorrhizal symbiosis. 3rd edn. Academic Press, London

Stobrawa K, Lorenc-Plucińska G (2007) Changes in carbohydrate metabolism in fine roots of the native European black poplar (Populus nigra L.) in a heavy-metal-polluted environment. Sci Total Environ 373:157-165

Timonen H, Aronen T, Laakso T, Saranpaa P, Chiang V, Haggman F, Niemi K (2008) Paxillus involutus forms and ectomycorrhizal symbiosis and enhances survival of PtCOMT- modified Betula pendula in vitro. Silvae Genet 57:235-242

Todeschini V, Franchin C, Castiglione S, Burlando B, Biondi S, Torrigiani P, Berta G, Lingua G (2007) Responses to copper of two registered poplar clones inoculated or not with arbuscular mycorrhizal fungi. Caryologia 60:146-155

Turnau K, Kottke I, Dexheimer J (1996) Toxic element filtering in Rhizopogon roseollus/Pinus sylvestris mycorrhizas collected from calamine dumps. Mycol Res 100:18-22

Turnau K, Orlowska E, Ryszka P, Zubek S, Anielska T, Gawronski S, Jurkiewicz A (2006) Role of mycorrhizal fungi in phytoremediation and toxicity monitoring of heavy metal rich industrial wastes in southern Poland. In: Twardowska S, Allen S, Häggblom S, Stefaniak S (eds) Soil and water pollution monitoring, protection and remediation. Springer, Berlin, pp 3-23

Vera-Estrella R, Miranda-Vergara MC, Barkla BJ (2009) Zinc tolerance and accumulation in stable cell suspension cultures and in vitro regenerated plants of the emerging model plant Arabidopsis halleri (Brassicaceae). Planta 229:977-986

Vozzo HE, Hacskalyo E (1974) Endo- and ectomycorrhizal associations in five Populus species. Bull Torrey Bot Club 101:182-186

Wang YP, Shi JY, Wang H, Lin O, Chen XC, Chen YX (2007) The influence of soil heavy metals pollution on soil microbial biomass, enzyme activity, and community composition near a copper smelter. Ecotoxicol Environ Saf 67:75-81

Zacchini M, Pietrini F, Mugnozza GS, Iori V, Pietrosanti L, Massacci A (2009) Metal tolerance, accumulation and translocation in poplar and willow clones treated with cadmium in hydroponics. Water Air Soil Pollut 197:23-34 